\title{
Phylogeography and dispersal in the velvet gecko (Oedura lesueurii), and potential implications for conservation of an endangered snake (Hoplocephalus bungaroides)
}

\author{
Sylvain Dubey ${ }^{1 *+}$, Benjamin Croak ${ }^{2+}$, David Pike ${ }^{2,3}$, Jonathan Webb ${ }^{2}$ and Richard Shine ${ }^{2}$
}

\begin{abstract}
Background: To conserve critically endangered predators, we also need to conserve the prey species upon which they depend. Velvet geckos (Oedura lesueurii) are a primary prey for the endangered broad-headed snake (Hoplocephalus bungaroides), which is restricted to sandstone habitats in southeastern Australia. We sequenced the ND2 gene from 179 velvet geckos, to clarify the lizards' phylogeographic history and landscape genetics. We also analysed 260 records from a longterm (3-year) capture-mark-recapture program at three sites, to evaluate dispersal rates of geckos as a function of locality, sex and body size.

Results: The genetic analyses revealed three ancient lineages in the north, south and centre of the species' current range. Estimates of gene flow suggest low dispersal rates, constrained by the availability of contiguous rocky habitat. Mark-recapture records confirm that these lizards are highly sedentary, with most animals moving $<30 \mathrm{~m}$ from their original capture site even over multi-year periods.

Conclusion: The low vagility of these lizards suggests that they will be slow to colonise vacant habitat patches; and hence, efforts to restore degraded habitats for broad-headed snakes may need to include translocation of lizards.
\end{abstract}

Keywords: Australia, Phylogeography, Dispersal, Reptile, Landscape genetics, Conservation

\section{Background}

To conserve an endangered species, we need to provide suitable habitat, shelter, prey items, and other resources (see e.g. [1-4]). Prey availability may be one of the most critical issues, especially for predators with specialized diets $[5,6]$. If management plans for endangered species include the restoration of habitat, we need to know if the endangered taxon itself is vagile enough to locate and colonise the newly-available sites. Evaluating the likelihood that significant prey species also will colonise restored areas is also important; if they do not do so (perhaps because of poor dispersal capacity), otherwise-

\footnotetext{
* Correspondence: sylvain.dubey@unil.ch

${ }^{\dagger}$ Equal contributors

'Department of Ecology and Evolution, Biophore Bld, University of Lausanne, Lausanne 1015, Switzerland

Full list of author information is available at the end of the article
}

suitable habitat may be unable to support populations of the endangered taxon.

The Broad-headed snake (Hoplocephalus bungaroides, Elapidae) is a small elapid snake restricted to rocky areas (sandstone plateaux) within a $200 \mathrm{~km}$ radius of Sydney, in south-eastern Australia [6]. These snakes were abundant at the time of European colonisation 200 years ago, but have now disappeared from most of its former range $[7,8]$. The threatening processes include habitat degradation and fragmentation resulting from the removal and destruction of critical shelter sites (especially, exfoliated rock that forms thermally-suitable retreat sites during the coldest parts of the year: [8]), forest overgrowth $[3,4,9]$ and illegal collection of animals for the pet trade [10]. Efforts at habitat restoration have produced encouraging results, with the snakes and their lizard prey rapidly colonising sites by themselves where artificial rocks have replaced stolen natural rocks [11] and where

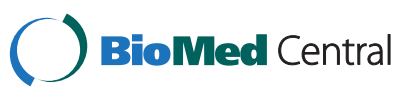


trimming of vegetation has allowed increased sunlight penetration [3,4]. However, these studies have focused on sites very close to extant populations of snakes and their prey; the prospectus for successful colonisation of more distant sites remains unclear.

For relatively isolated habitat patches to be colonised, both the snakes and their prey must be able to reach them. Landscape-genetic analyses have confirmed that broad-headed snakes often move between adjacent outcrops (distance between outcrops: 0.9 to $10.7 \mathrm{~km}$ ), and thus are likely to rapidly find any restored habitat patches [12]. The probability of colonisation by the snakes' prey species has not been studied, and is the subject of the present paper. Broad-headed snakes consume a diversity of vertebrate prey taxa, but the most important taxon (especially during cooler months of the year, when the snakes are restricted to rock outcrops) is the velvet gecko (Oedura lesueurii, Diplodactylidae: [6]). Indeed, velvet geckos comprised $70 \%$ of prey items consumed by juvenile $H$. bungaroides [6]. Like $H$. bungaroides, $O$. lesueurii is restricted to rock outcrops $[13,14]$. The predator-prey interaction between these two taxa presumably has been a long-running one, because geckos from populations sympatric with this snake species are reported to display a suite of antipredator tactics not seen in conspecific geckos from populations allopatric to broad-headed snakes ([15]; but see [16] for data that challenge this conclusion). Local coadaptation is likely only when gene flow is restricted between populations (e.g. $[15,17,18])$, allowing the evolution of spatial heterogeneity in relevant traits.

To evaluate the history of this predator-prey interaction, we need to know the timeline not only for the predator's evolution [12] but also for the prey's evolution (current study). Because O. lesueurii is an important prey species for $H$. bungaroides, we also need to evaluate the potential for $O$. lesueurii to colonise newly restored areas of rocky habitat. We can clarify this issue with a study of landscape genetics (e.g., what are the spatial scales of current and historical rates of gene flow?) and direct measures of dispersal, based on mark-recapture fieldwork.

\section{Results}

\section{Phylogenetic analyses and molecular dating}

The 179 samples of O. lesueurii showed 29 haplotypes (H1-H29, [Genbank: JQ779339-JQ779366]) of $710 \mathrm{bp}$. The complete dataset included 369 variable sites of which 237 were parsimony-informative. As the two phylogenetic methods showed similar arrangements of the main branches, Figure 1 only shows the relationship between haplotypes for the ML analyses (see Additional file 1 for the MP tree). Three main lineages are present within the study area, the first (A) including populations from the north and central areas (Putty, Malabar, and Cape Banks; ML and MP analyses show bootstrap support of $96 \%$ an $90 \%$ respectively), the second (B) restricted to populations from the south (Morton; ML and MP analyses show bootstrap support of $100 \%$ and 99\%), and the third (C) strictly central populations (Dharawal and Royal NP sites; ML and MP analyses show support of $84 \%$ and $77 \%$ ). The mean $\mathrm{K} 2 \mathrm{P}$ distance between the lineages was $3.7,3.5$, and $4.3 \%$ for A-C, B-C, and A-B respectively.

Dating analyses based on the secondary calibration points revealed a first divergence within $O$. lesueurii about 5.68 million years ago (Ma; 95\% HPD: $2.73-$ 10.76), with a split between haplotypes within lineages occurring 2.94 Ma (95\% HPD: 1.21 - 5.18), 1.07 (95\% HPD: 0.28-0.94), and 1.58 (95\% HPD: 0.50 - 2.96) for A, $\mathrm{B}$, and $\mathrm{C}$ respectively. Dating analyses based on a standard divergence rate of $1.3 \%$ (derived from numerous previous studies; see Methods section) gave similar results, with a first divergence within the species about $5.00 \mathrm{Ma}$ (95\% HPD: 2.88 - 8.06), with a split between haplotypes within lineages occurring $2.36 \mathrm{Ma}$ (95\% HPD: $1.30-$ 3.96), $0.83 \mathrm{Ma}$ (95\% HPD: $0.30-1.83$ ), and $1.25 \mathrm{Ma}$ (95\% HPD: $0.56-2.53$ ) for A, B, and C respectively.

\section{Population and landscape genetic analyses}

Overall, the $\phi_{\mathrm{ST}}$ between populations varied from 0 to 1.0 (see Additional file 2, with a mean value of 0.81 . The mean of the pairwise $\phi_{\mathrm{ST}}$ value within each lineage was $0.62,0.52$, and 0.24 for $\mathrm{A}, \mathrm{B}, \mathrm{C}$ respectively.

Based on the Mantel and partial Mantel tests, the observed genetic structure $\left(\phi_{\mathrm{ST}}\right)$ in Oedura lesueurii populations was best predicted by a combination of distance and minimum elevation between sites (AIC value $=$ -257.78 ; AIC weight $=0.27 ; R^{2}=57.87$; straight-line distance, partial corr.: 0.56; minimum elevation, partial corr.: -0.51; Table 1). The second-best model included the number of rivers, the minimum elevation and the distance between sites (AIC value $=-257.72$; AIC weight $=0.26$; $R^{2}=58.85$; rivers, partial corr.: -0.44 ; minimum elevation, partial corr.: -0.61 ; straight-line distance, partial corr.: 0.15). Three more models deviated from the best model by less than two units (i.e., $\Delta$ AIC $<2$ ), and all these models include the minimum elevation and the straight-line distance between sites as explanatory variables, further indicating the importance of these parameters. Because the true distance between sites was less informative than the straight-line distance (straightline distance, $R^{2}=31.48$; true distance, $R^{2}=20.78$ ), we used latter variable in our analyses (see Table 1).

The nucleotide diversity at a site tended to increase with latitude (i.e., was higher at more northern sites; $F_{1,19}=13.88, P=0.002^{*}$; Figure 2), and we did not detect any significant relationships between nucleotide diversity 


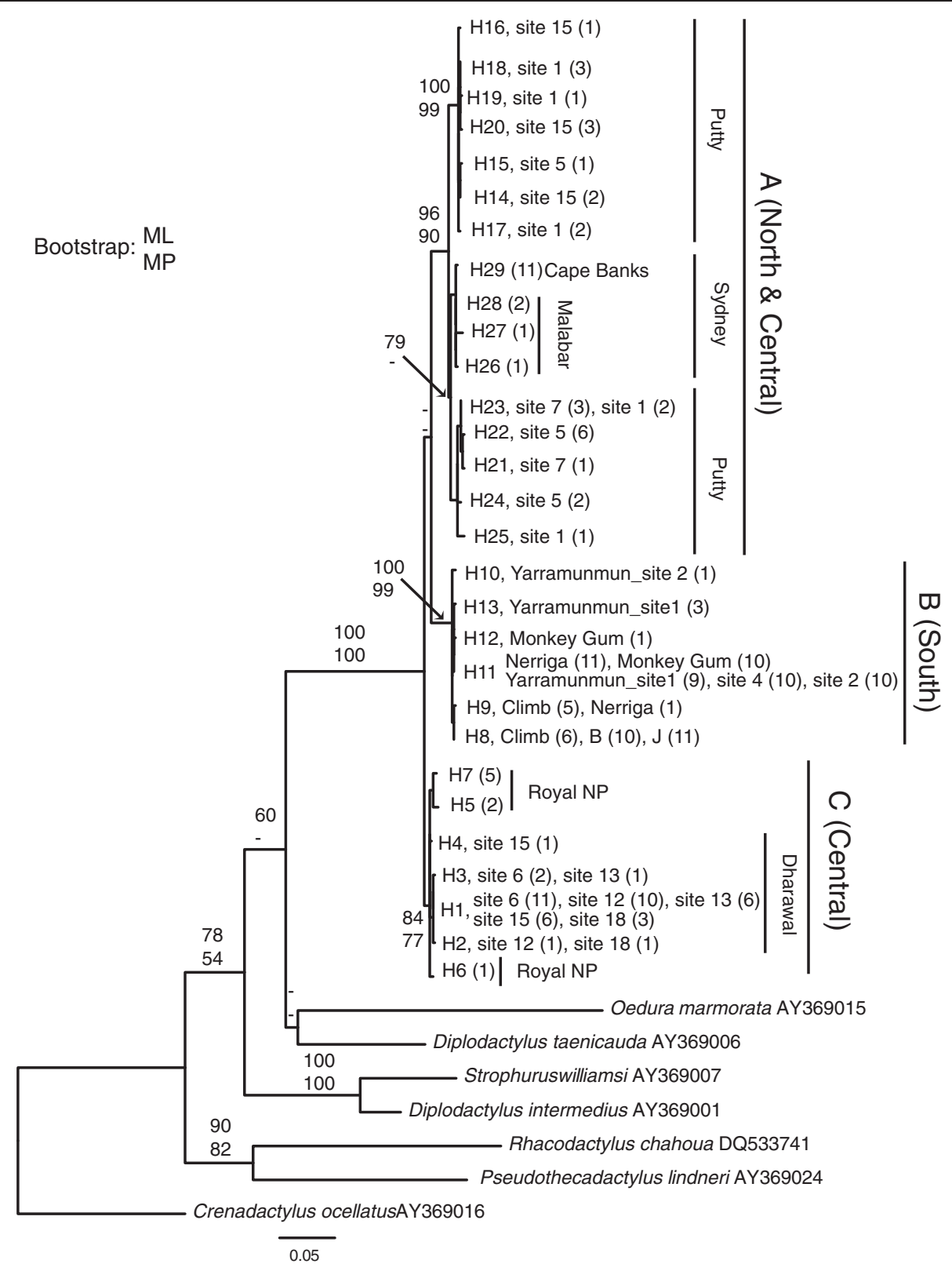

Figure 1 Geographical distribution of the gecko (Oedura lesueurii) tissue samples used for genetic analyses, with mean $\varphi_{\text {ST }}$ values and K2P distance between lineages ( $A, B$, and $C$ ).

and the number of samples, the elevation, or the longitude of sites.

The SAMOVA revealed high $F_{\mathrm{CT}}$ (among population groups) values for all the groups and small $F_{\mathrm{SC}}$ (within population group) values in cases of 9 to 19 groups, indicating very high population structure. For example, at $K=9$ the majority of variation $(94.32 \%)$ is among groups, although $0.03 \%$ of variation at the level of among populations within groups still represents highly significant population structuring in the remaining population groups $(P<0.001)$. At $K=2$, the two clusters identified were the populations of lineage B (Morton) vs lineages A (Putty, Malabar, and Cape Banks) and C (Dharawal and Royal NP), and at $\mathrm{K}=3$, the three clusters were the populations of lineage $\mathrm{A}, \mathrm{B}$, and $\mathrm{C}$.

\section{Dispersal distances of free-ranging geckos}

In total, we obtained records of the distances moved by 260 geckos, over time periods ranging from 24 to 928 days between recaptures (average time between recaptures $=203.1$ days). We used ANOVA to compare gecko movements among regions and between sexes 
Table 1 Results of mantel and partial mantel test of landscape genetics of the gecko Oedura lesueurii, with a listing of variables included in the models (number of rivers [River] and number of roads [Walking track; Dirt Road; Paved Road; All road] between sites, minimum elevation between sites sites [min. elevation], mean elevation of sites minus the minimum elevation between sites [Mean elevation - min. elevation], straight-line distance [Distance] and true distance between sites [True distance]), the number of parameters per model, $\mathbf{R}^{2}$ (total variance explained by the model), coefficient of correlation, P-value of parameters (The level of significance for our tests was set at $\alpha=0.0028$ (Bonferroni correction; i.e. $\mathbf{0 . 0 5 / 1 8}=\mathbf{0 . 0 0 2 8}$, where 18 represents the number of tests performed), AIC, $\triangle \mathrm{AIC}$, and AIC weight

\begin{tabular}{|c|c|c|c|c|c|c|c|}
\hline Variable & $\mathrm{K}$ & R2 & Coeff corr. & P-value & AIC & $\triangle \mathrm{AIC}$ & AIC w \\
\hline Distance \& min. elevation & 3 & 57.87 & & & -257.78 & I & 0.2686 \\
\hline Distance & & & 0.56 & $0.0001 *$ & & & \\
\hline Min. elevation & & & -0.51 & $0.0001^{*}$ & & & \\
\hline River \& Min. elevation \& distance & 4 & 58.85 & & & -257.72 & 0.06 & 0.2606 \\
\hline River & & & -0.44 & $0.0001^{*}$ & & & \\
\hline Min. elevation & & & -0.61 & $0.0001^{*}$ & & & \\
\hline Distance & & & 0.15 & 0.0362 & & & \\
\hline River \& Dirt road \& Distance \& Min. Elevation & 5 & 59.13 & & & -256.29 & 1.49 & 0.1275 \\
\hline River & & & -0.44 & $0.0001^{*}$ & & & \\
\hline Dirt road & & & 0.19 & 0.0085 & & & \\
\hline Distance & & & 0.37 & $0.0001^{*}$ & & & \\
\hline Min. elevation & & & -0.47 & $0.0001^{*}$ & & & \\
\hline Min. elevation \& Dirt road \& distance & 4 & 58.08 & & & -256.20 & 1.58 & 0.1219 \\
\hline Min. elevation & & & -0.75 & $0.0001^{*}$ & & & \\
\hline Dirt road & & & 0.15 & 0.0465 & & & \\
\hline Distance & & & 0.06 & 0.3982 & & & \\
\hline Distance \& mean - min. elevation \& min. elevation & 4 & 57.87 & & & -255.79 & 1.99 & 0.0993 \\
\hline Min. elevation & & & -0.75 & $0.0001^{*}$ & & & \\
\hline Mean - min. elevation & & & 0.05 & 0.4932 & & & \\
\hline Distance & & & 0.14 & 0.0516 & & & \\
\hline Min. elevation & 2 & 55.59 & -0.75 & $0.0001^{*}$ & -255.44 & 2.34 & 0.0834 \\
\hline Min. elevation \& mean - min. elevation & & 55.84 & & & -253.91 & 3.87 & 0.0388 \\
\hline Min. elevation & 3 & & -0.75 & $0.0001^{*}$ & & & \\
\hline Mean - min. elevation & & & 0.05 & 0.4870 & & & \\
\hline Distance \& mean elevation - min. elevation & 3 & 39.71 & & & -228.22 & 29.56 & 0.0000 \\
\hline Distance & & & 0.56 & $0.0001^{*}$ & & & \\
\hline Mean elevation - min. elevation & & & 0.29 & $0.0002^{*}$ & & & \\
\hline Distance \& river & 3 & 36.65 & & & -224.13 & 33.65 & 0.0000 \\
\hline Distance & & & 0.56 & $0.0001^{*}$ & & & \\
\hline River & & & -0.23 & $0.0019^{*}$ & & & \\
\hline Distance \& dirt road & 3 & 31.49 & & & -217.67 & 40.11 & 0.0000 \\
\hline Distance & & & 0.56 & $0.0001^{*}$ & & & \\
\hline Dirt road & & & 0.01 & 0.9289 & & & \\
\hline
\end{tabular}

Only Mantel and partial Mantel tests (total of 18) with the 10 best AIC values are shown.

In grey, best model (bold) and models with a $\triangle \mathrm{AIC}<2$.

and age classes over time. There were no significant interaction effects, so we only describe main effects. Oedura lesueurii was highly sedentary. Marked lizards did not tend to move further away from their initial capture site with increasing time $\left(\mathrm{F}_{2,252}=2.08, \mathrm{P}=0.15\right)$, indicating that they have fixed home ranges. There was no difference in mean movement distances between male, female or juvenile geckos $\left(F_{2,252}=1.84, P=0.16\right)$, 


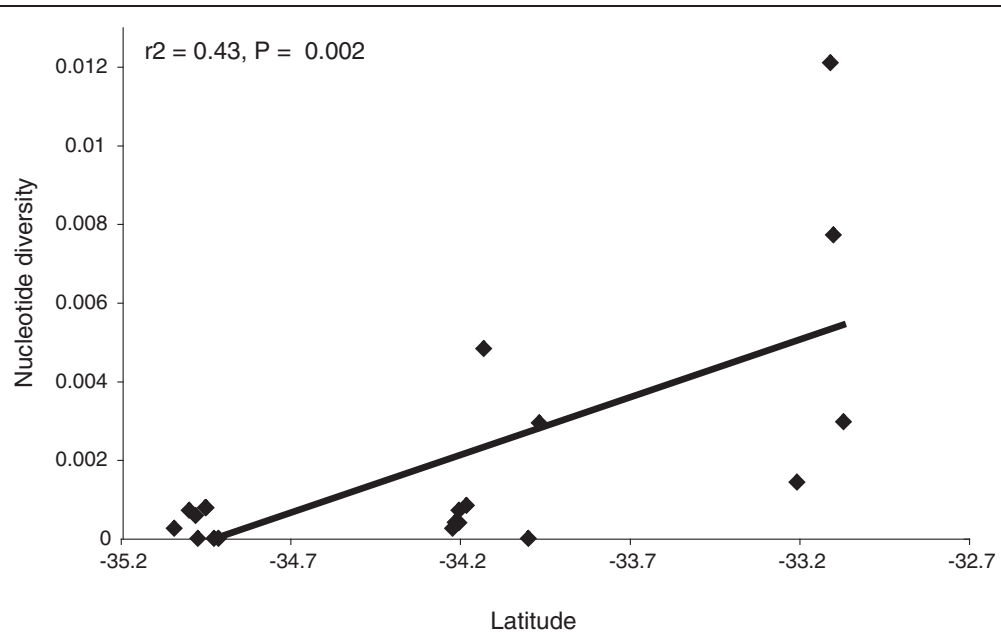

Figure 2 Phylogeny of the ND2 fragment of the gecko Oedura lesueurii in southeastern Australia, analysed using a maximum likelihood procedure. Values in branches are indices of support for the major branches for maximum likelihood (ML) and maximum parsimony (MP) analyses (percentage of 1000 replications for ML and MP).

and the average distances moved were less than $30 \mathrm{~m}$ (Figure 3). The maximum dispersal distances recorded were $1.648 \mathrm{~km}$ for an adult male, $1.442 \mathrm{~km}$ for an adult female, and $1.577 \mathrm{~km}$ for a juvenile.

\section{Discussion}

Our study revealed ancient genetic divergences within Oedura lesueurii from southeastern Australia, beginning in the Miocene-Pliocene (5.68 - 5.0 Ma) and resulting in three geographically well-defined lineages (North, Central, and South; Figures 4, 1). Similarly, our population genetics analyses showed a strong spatial structure among our 20 populations as well as within lineages, with a lack of haplotype sharing between populations separated by only $3.7 \mathrm{~km}\left(\phi_{\mathrm{ST}}=0.70\right)$. In addition, our landscape genetic analyses identified distance as the major barrier to gene flow $\left(\phi_{\mathrm{ST}}\right)$ between populations. In contrast, an absence of areas with low elevation between

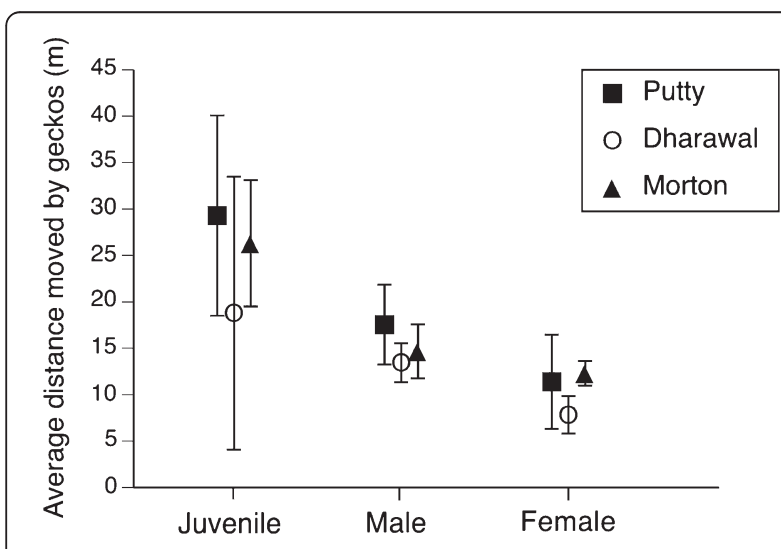

Figure 3 Relationship between the latitude of a site, and the nucleotide diversity of the gecko Oedura lesueurii within that site. sites (e.g. the absence of deep valleys separating populations) favoured dispersal. In this case, areas of high elevation between sites reflects continuous favourable habitat (e.g. rocky outcrops). Similarly, gene flow in the broad-headed snake $H$. bungaroides mostly occurs along sandstone plateaux rather than across the densely forested valleys that separate plateaux [12]. Consistent with these genetic analyses, our field data (5 years of mark-recapture studies) revealed that $O$. lesueurii are sedentary. Marked individuals typically remained within close proximity (tens of metres) to their original capture site for years, consistent with earlier reports that some females return to their natal sites to lay eggs [14]. Previous phylogenetic studies on southeastern Australian reptiles (e.g. $[19,20])$ have revealed similar ancient splits between populations.

In both of these taxa, a southern lineage (restricted to Morton NP) differs significantly from conspecifics in the Sydney area. Sumner et al. [20] suggested that the break between the southern and northern clade of $H$. bungaroides occurs in a geologically distinctive area where volcanic soils cover the sandstone plateaux [21], acting as a barrier to gene flow. The same may be true of other sandstone specialist species such as $O$. lesueurii. The strong genetic structure observed in this study is consistent with general patterns observed in various taxa distributed in eastern Australia [22] and could be attributed to the ancestral position of the mesic biome (which dominates eastern Australia), and hence allowed localized endemism from long term persistence of populations through multiple climatic cycles [22]. Finally, the observed gradient of genetic diversity in $O$. lesueurii throughout the study area (decreasing diversity with increasing latitude) may be the result of harsher historical 


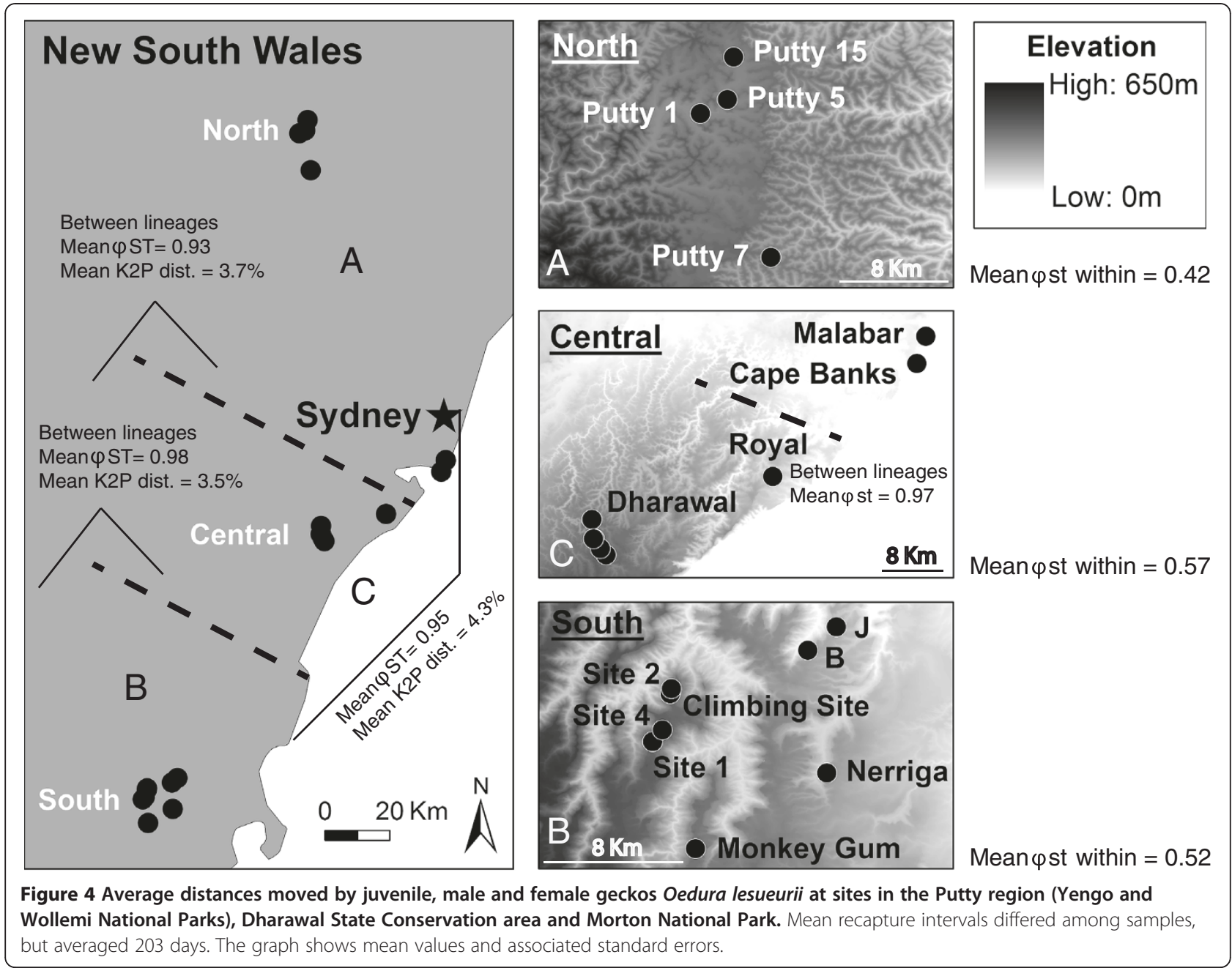

conditions in the southern part of the range (Last Glacial Maximum; [23]). The species reaches its current southern distributional limit close to our study sites in Morton NP [24].

Overall, the diversification of Australian geckos is ancient and may have originated from a Gondwanan vicariance (e.g. about $70 \mathrm{Ma}$ for the diplodactyloids: Oliver and Sanders, 2009). In this respect the geckos differ from most other squamates, which colonized Australia from Asia more recently (e.g. [25-28]). Similarly, Australian geckos show relatively ancient intraspecific diversification (see e.g. [29-32]; this study). The diversification of at least one of the gecko's major predators (the broadheaded snake $H$. bungaroides) is much more recent, as the split between the genera Hoplocephalus and Paroplocephalus occurred less than $3 \mathrm{Ma}$ [26], and the oldest split between $H$. bungaroides lineages about $0.8 \mathrm{Ma}$ [20]. Consequently, O. lesueurii was established across much of its current range in southeastern Australia long before the evolutionary origin of $H$. bungaroides. Our results support the plausibility of the conditions required for natural selection to produce adaptive local differentiation in geckos: that is, genetic variation among populations and low gene flow between them [33,34].

\section{Conclusions}

From a conservation perspective, the low dispersal rates of $O$. lesueurii have two main implications. The first is that this gecko will be slow to recolonise any local areas from which it is extirpated (perhaps by chance abiotic events, predators, or human disturbance). Thus, habitat suitability for the endangered broad-headed snake may be spatially heterogeneous as a result of relatively ancient local events that reduced gecko numbers. Second, the low dispersal rates of the geckos need to be considered in any management plan that includes the restoration of degraded habitat previously hosting $H$. bungaroides. The poor dispersal capacity of O. lesueurii (unlike H. bungaroides itself; [12]) likely will delay or prevent natural recolonisation of geckos in restored areas, unless those areas are very close to extant populations. Consequently, we may need to reintroduce 
O. leseurii to such areas in order to guarantee successful habitat restoration for $H$. bungaroides.

\section{Methods}

\section{Tissue collection}

We collected tissue samples from 179 geckos representing 20 populations in southeastern Australia (see Figure 4 and Table 2), by turning rocks and capturing animals by hand. Tissues were collected by toe-clipping, or from voluntary tail autotomy. Tissue samples were placed in $100 \%$ ethanol, transported to the laboratory and stored below $0^{\circ} \mathrm{C}$ prior to processing.

\section{DNA extraction and PCR amplification}

We placed tissues in $200 \mathrm{~mL}$ of $5 \%$ Chelex containing $0.2 \mathrm{mg} / \mathrm{mL}$ of proteinase $\mathrm{K}$, incubated them overnight at $56^{\circ} \mathrm{C}$, boiled them at $100^{\circ} \mathrm{C}$ for $10 \mathrm{~min}$, and centrifuged them at $13,300 \mathrm{~g}$ for $10 \mathrm{~min}$. The supernatant, containing purified DNA, was then removed and stored at $-20^{\circ} \mathrm{C}$.

Double-stranded DNA amplifications of NADH dehydrogenase 2 (ND2) were performed with the primer pairs AT4882 (5'caacatgacaaaaattrgcccc 3'; see [35])/ ND2R2 (5' ratctaggaggccttakc 3'; specifically designed for this study). Amplification conditions included a hot start denaturation of $95^{\circ} \mathrm{C}$ for $3 \mathrm{~min}$, followed by 35 cycles of $95^{\circ} \mathrm{C}$ for $1 \mathrm{~min}, 55^{\circ} \mathrm{C}$ annealing temperature for $1 \mathrm{~min}, 72^{\circ} \mathrm{C}$ for 1 minute 45 seconds. We then performed a final extension of $72^{\circ} \mathrm{C}$ for $7 \mathrm{~min}$ and visualized the sequence reactions on a $3730 \mathrm{xl}$ DNA Analyzer (Applied Biosystems, CA, USA).

\subsection{Phylogenetic analyses}

We aligned sequences using BioEdit [36] and assessed them by eye. A sequence of Crenadactylus ocellatus ([GenBank:AY369016]; the basal species of the Diplodactylidae according to [28]) was used to root the tree. Additional sequences of Diplodactylidae were included in the analyses: Pseudothecadactylus lindneri [GenBank: AY369024], Rhacodactylus chahoua [GenBank:DQ533741], Oedura marmorata [GenBank:AY369015], Diplodactylus taenicauda [GenBank:AY369006], Diplodactylus intermedius [GenBank:AY369001], and Strophurus williamsi [GenBank: AY369007].

We performed ML heuristic searches and bootstrap analyses (1000 replicates) with phyml [37] and we selected the model of DNA substitution using jModelTest 0.1.1 [37,38]. The HKY + G model [39] best fitted the dataset with a Bayesian Information Criterion (BIC; [40]). Finally, we used Paup* 4.0b10 [41] to perform maximum parsimony (MP) analyses using 100 random additions of sequences followed by tree bisection and

Table 2 Number of tissue samples of the gecko Oedura lesueurii, and the longitude, latitude, and elevation, length and width of the collecting site, the number of samples and of haplotypes, and the nucleotide diversity at that site

\begin{tabular}{|c|c|c|c|c|c|c|c|c|}
\hline Sites & Long. & Lat. & Elevation $(\mathrm{m})$ & Length $(\mathrm{m})$ & Width (m) & \# samples & \# hapl. & Nuc div. \\
\hline Dharawal Site 6 & 150.8739 & -34.2025 & 334 & 93 & 44 & 13 & 2 & 0.000403 \\
\hline Dharawal Site 12 & 150.8873 & -34.2213 & 439 & 71 & 60 & 11 & 2 & 0.00026 \\
\hline Dharawal Site 13 & 150.8807 & -34.2139 & 382 & 73 & 60 & 7 & 2 & 0.000408 \\
\hline Dharawal Site 15 & 150.8709 & -34.1801 & 268 & 234 & 191 & 7 & 2 & 0.00084 \\
\hline Dharawal Site 18 & 150.8726 & -34.2027 & 335 & 105 & 76 & 4 & 2 & 0.000714 \\
\hline Climb_Morton & 150.3770 & -34.9505 & 393 & 340 & 20 & 11 & 2 & 0.000779 \\
\hline Nerrigera_Morton & 150.4695 & -34.9973 & 201 & 800 & 50 & 12 & 2 & 0.000716 \\
\hline B_Morton & 150.4583 & -34.9248 & 234 & 172 & 25 & 10 & 1 & 0 \\
\hline J_Morton & 150.4752 & -34.9109 & 211 & 187 & 15 & 11 & 1 & 0 \\
\hline MonkeyGum & 150.3919 & -35.0420 & 367 & 5000 & 10 & 11 & 2 & 0.00026 \\
\hline Yarramunmun site 1 & 150.3666 & -34.9788 & 395 & 1100 & 50 & 12 & 2 & 0.000584 \\
\hline Yarramunmun site 4 & 150.3724 & -34.9719 & 392 & 700 & 50 & 10 & 1 & 0 \\
\hline Yarramunmun site 2 & 150.3777 & -34.9475 & 395 & 1200 & 50 & 11 & 2 & 0.000781 \\
\hline Putty_site 7 & 150.7251 & -33.2068 & 271 & 216 & 97 & 4 & 2 & 0.001433 \\
\hline Putty_site 15 & 150.6998 & -33.0697 & 266 & 77 & 30 & 5 & 3 & 0.002873 \\
\hline Putty_site 5 & 150.6954 & -33.0987 & 325 & 178 & 40 & 9 & 3 & 0.007716 \\
\hline Putty_site 1 & 150.6769 & -33.1084 & 294 & 241 & 42 & 8 & 5 & 0.012807 \\
\hline Malabar & 151.2602 & -33.9666 & 15 & 350 & 80 & 4 & 3 & 0.002933 \\
\hline Cape Banks & 151.2496 & -33.9983 & 15 & 950 & 60 & 11 & 1 & 0 \\
\hline Royal NP & 151.0816 & -34.1297 & 117 & 400 & 10 & 8 & 3 & 0.004823 \\
\hline
\end{tabular}


reconnection branch swapping, and retaining at most 100 trees at each replicate. We estimated branch support using 1000 bootstrap replicates with the same heuristic settings.

\section{Population and landscape genetic analyses}

We estimated population structure between all sites sampled by calculating $\phi_{\mathrm{ST}}$, taking into account haplotype frequencies and the genetic distance between haplotypes, in Arlequin 3.0 [42]. We used the Kimura two-parameter genetic distance (K2P; [43]) as our genetic model.

We performed Mantel and partial Mantel tests [44] using the software FSTAT Version 2.9.3.2 [45], with genetic distance as the dependent variable. The independent variables were the number of intervening rivers (River; i.e. the number of rivers crossing the strait-line distance between two locations) and roads (Walking track; Dirt Road; Paved Road; All roads) between sites, the minimum elevation between sites, the mean elevation of sites minus the minimum elevation between sites, the straight-line distance and true distance between site (i.e., by calculating the surface length of a line connecting each pair of sites while incorporating an underlying digital elevation model at a resolution of $25 \mathrm{~m}$; implemented using the 3D Analyst Tool in ArcMap 9.3, 9). P-values were calculated after 10,000 randomizations. The level of significance for our tests was set at $\alpha=0.0028$ (Bonferroni correction; i.e. $0.05 / 18=0.0028$, where 18 represents the number of tests performed). Based on the results of the Mantel and partial Mantel tests, we selected the best model using Akaike's information criterion (AIC; [46]; based on the variance of the residuals). We compared each candidate model based on its AIC scores and weights. The best supported models are those with high Akaike weights, and that deviate from the best model by less than two units (i.e., $\triangle \mathrm{AIC}<2$; [47]).

We used the program SAMOVA 1.0 [48] to characterise population structure and to define groups of populations using genetic criteria. Given an a priori number of clusters $(K)$, the software uses a simulated annealing procedure to define the cluster composition in which populations within a cluster are as genetically homogeneous as possible ( $F_{\mathrm{SC}}$ minimised) and clusters are maximally differentiated from each other $\left(F_{\mathrm{CT}}\right.$ maximised; [48]). The analysis was run for $K=2$ to $K=19$ and the significance of fixation indices was tested by 1023 permutations.

\section{Molecular dating}

We performed dating analyses using Beast 1.6.2 [49] with an uncorrelated lognormal relaxed clock and a coalescent tree prior. The coefficient of variation frequency histogram did not abut against zero, meaning that there was among-branch rate heterogeneity within our data
[50]. Consequently, as suggested by Drummond et al. [50], we used a relaxed molecular clock.

We used two secondary calibration points from a robust phylogeny focusing on Australasian geckos [28]: (1) The oldest split within the Diplodactylidae (i.e. between Crenadactylus ocellatus and the other members of the family: 66.2 Ma [95\% HPD: 46.6-87.0]) and (2) the split between Pseudothecadactylus and the New Caledonian Rhacodactylus chahoua and the remaining members of the Diplodactylidae (60.3 Ma [95\% HPD: 41.5-79.2]).

The analysis was performed with two independent chains and 20 million generations; chains were sampled every 1000 generations with a burn-in of 2 million generations. Additional simulations were run with the same dataset and the same models, but strictly based on a rate of divergence of $1.3 \%$ derived from numerous studies as e.g. Zamudio \& Greene's [51] study on snake mtDNA and from Macey's et al. ([52]; also used in e.g. [35,53,54]) work on lizards.

\section{Dispersal distances of free-ranging geckos}

We conducted mark-recapture surveys on velvet geckos by turning rocks and measuring, individually marking (by toe-clipping) and releasing any geckos found. These studies were conducted in and around Morton National Park (Morton) on a monthly basis between March 2007 and October 2009, and in Dharawal Conservation area (Dharawal) and Yengo and Wollemi National Park (collectively, Putty) from March 2008 until November 2010. We classified geckos as adult males if they were $>40 \mathrm{~mm}$ snout-vent length (SVL) with overt hemipenial bulges; adult females if they were $>40 \mathrm{~mm}$ SVL and without such bulges; and juveniles if they were $<40 \mathrm{~mm}$ SVL. We determined the distance between rocks used by individual O. lesueurii using GPS co-ordinates imported into ArcGIS $10.0[55]$.

\section{Additional files}

Additional file 1: Maximum parsimony (MP) consensus tree $(50 \%$ majority rule).

Additional file 2: Pairwise ФST values between populations and p-values.

\section{Competing interests}

The authors declare that they have no competing interests.

\section{Authors' contributions}

SD, BC, DP, JW and RS contributed with the conceptual development of the work and the writing of the manuscript. SD, DP, BC, and JW collected samples and data in the field. SD, BC, DP carried out the analyses. All authors read and approved the final version of the manuscript.

\section{Acknowledgements}

We thank the Australian Research Council and the Swiss National Science Foundation for funding, and Reid Tingley for assistance with GIS analyses. The work was authorized by the University of Sydney Animal Care and Ethics Committee. 


\section{Author details}

'Department of Ecology and Evolution, Biophore Bld, University of Lausanne, Lausanne 1015, Switzerland. ${ }^{2}$ School of Biological Sciences, University of Sydney, Sydney, NSW 2006, Australia. ${ }^{3}$ School of Marine and Tropical Biology, James Cook University, Townsville, QLD, Australia.

Received: 15 March 2012 Accepted: 2 May 2012

Published: 14 May 2012

\section{References}

1. Finnoff D, Tschirhart J: Protecting an endangered species while harvesting its prey in a general equilibrium ecosystem model. Land Economics 2003, 79:160-180

2. Hanson MB, Baird RW, Ford JKB, et al: Species and stock identification of prey consumed by endangered southern resident killer whales in their summer range. Endang Species Res 2010, 11:69-82.

3. Pike DA, Webb JK, Shine R: Removing forest canopy cover restores a reptile assemblage. Ecol App/ 2011, 21:274-280.

4. Pike DA, Webb JK, Shine R: Chainsawing for conservation: ecologicallyinformed tree removal for habitat management. Ecol Manag Restor 2011 12:110-118.

5. Boyles JG, Storm JJ: The perils of picky eating: dietary breadth is related to extinction risk in insectivorous bats. PLoS One 2007, 2:e672.

6. Webb JK, Shine R: Ecological characteristics of a threatened snake species, Hoplocephalus bungaroides (Serpentes, Elapidae). Anim Conserv 1998, 1:185-193.

7. Krefft G: The Snakes of Australia: An Illustrated and Descriptive Catalogue of all the Known Species. Government Printer, Sydney: Thomas Richards; 1869.

8. Shine R, Webb JK, Fitzgerald M, Sumner J: The impact of bush-rock removal on an endangered snake species, Hoplocephalus bungaroides (Serpentes: Elapidae). Wildlife Res 1998, 25:285-295.

9. Pringle RM, Webb JK, Shine R: Canopy structure, microclimate and habitat selection by a nocturnal snake, Hoplocephalus bungaroides. Ecology 2003, 10:2668-2679.

10. Webb JK, Brook BW, Shine R: Collectors endanger Australia's most threatened snake, the broad-headed snake Hoplocephalus bungaroides. Oryx 2002, 2:170-181.

11. Croak BM, Pike DA, Webb JK, Shine R: Using artificial rocks to restore nonrenewable shelter sites in human-degraded systems: colonization by fauna. Restor Ecol 2010, 4:428-438.

12. Dubey S, Sumner J, Pike DA, Keogh JS, Webb JK, Shine R: Genetic connectivity among populations of an endangered snake species from southeastern Australia (Hoplocephalus bungaroides, Elapidae). Ecol Evol 2011, 1:218-227.

13. Schlesinger CA, Shine R: Choosing a rock: perspectives of a commercial bush-rock collector and a saxicolous lizard. Biol Conserv 1994, 67:49-56.

14. Webb JK, Pike D, Shine R: Population ecology of the velvet gecko, Oedura lesueurii in southern Australia: implications for the persistence of an endangered snake. Aust Ecol 2008, 33:839-847.

15. Downes S, Adams M: Geographic variation in antisnake tactics: The evolution of scent-mediated behavior in a lizard. Evolution 2001, 3:605-615.

16. Webb JK, Du WG, Pike DA, Shine R: Chemical cues from both dangerous and non-dangerous snakes elicit antipredator behaviours from a nocturnal lizard. Anim Behav 2009, 77:1471-1478.

17. Riechert SE: Investigation of potential gene flow limitation of behavioral adaptation in an arid lands spider. Behav Ecol Sociobiol 1993, 32:355-363.

18. Pafilis P, Foufopoulos J, Poulakakis N, Lymberakis P, Valakos ED: Tail shedding in island lizards [Lacertidae, Reptilia]: decline of antipredator defenses in relaxed predation environments. Evolution 2009, 63:1262-1278

19. Dubey S, Shine R: Evolutionary diversification of the lizard genus Bassiana (Scincidae) across southern Australia. PLoS One 2010, 5:e12982.

20. Sumner J, Webb JK, Shine R, Keogh JS: Molecular and morphological assessment of Australia's most endangered snake, Hoplocephalus bungaroides reveals two evolutionary significant units for conservation. Conserv Genet 2010, 11:747-758.

21. Branagan D, Packham G: Field Geology of New South Wales. Revised editionth edition. UNSW: NSW Department of Mineral Resources; 2000

22. Byrne M, Steane DA, Joseph L, Yeates DK, Jordan GJ, Crayn D, Aplin K, Cantrill DJ, Cook LG, Crisp MD, Keogh JS, Melville J, Moritz C, Porch N,
Sniderman JMK, Sunnucks P, Weston PH: Decline of a biome: evolution, contraction, fragmentation, extinction and invasion of the Australian mesic zone biota. J Biogeogr 2011, 38:1635-1656.

23. Markgraf V, McGlone M, Hope G: Neogene paleoenvironmental and paleoclimatic change in southern temperate ecosystems - a southern perspective. Trends Ecol Evol 1995, 10:143-147.

24. Wilson S, Swan G: A complete guide to reptiles of Australia. New Holland Publisher: Third edition; 2010

25. Hugall AF, Foster R, Hutchinson M, Lee MSY: Phylogeny of Australasian agamid lizards based on nuclear and mitochondrial genes: implications for morphological evolution and biogeography. Biol J Linn Soc 2008, 93:343-358.

26. Sanders KL, Lee MSY, Leys R, Foster R, Keogh JS: Molecular phylogeny and divergence dates for Australasian elapids and sea snakes (hydrophiinae): evidence from seven genes for rapid evolutionary radiations. J Evol Biol 2008, 3:682-695

27. Skinner A, Lee SYM, Hutchinson MH: Rapid and repeated limb loss in a clade of scincid lizards. BMC Evol Biol 2008, 8:310.

28. Oliver PM, Sanders KL: Molecular evidence for Gondwanan origins of multiple lineages within a diverse Australasian gecko radiation. J Biogeogr 2009, 36:2044-2055.

29. Oliver P, Hugall A, Adams M, Cooper SJB, Hutchinson M: Genetic elucidation of cryptic and ancient diversity in a group of Australian diplodactyline geckos: the Diplodactylus vittatus complex. Mol Phylogenet Evol 2007, 44:77-88.

30. Oliver PM, Adams M, Doughty P: Molecular evidence for ten species and Oligo-Miocene vicariance within a nominal Australian gecko species (Crenadactylus ocellatus, Diplodactylidae). BMC Evol Biol 2010, 10:386.

31. Oliver PM, Bauer AM: Systematics and evolution of the Australian knobtail geckos (Nephrurus, Carphodactylidae, Gekkota): plesiomorphic grades and biome shifts through the Miocene. Mol Phylogenet Evol 2011 59:664-674

32. Dubey $S$, Shine R: Geographic variation in the age of temperate-zone reptile and amphibian species: southern Hemisphere species are older. Biol Letters 2011, 7:96-97.

33. Endler JA: Natural selection in the wild. NJ: Princeton Univ. Press; 1986.

34. Urban MC: Microgeographic adaptations of spotted salamander morphological defenses in response to a predaceous salamander and beetle. Oikos 2010, 119:646-658.

35. Dubey S, Shine R: Restricted dispersal and genetic diversity in populations of an endangered montane lizard (Eulamprus leuraensis, Scincidae). Mol Ecol 2010, 19:886-897.

36. Hall TA: BioEdit: a user-friendly biological sequence alignment editor and analysis program for Windows 95/98/NT. Nucleic Acids Symp Ser 1999, 41:95-98.

37. Guindon S, Gascuel O: A simple, fast, and accurate algorithm to estimate large phylogenies by maximum likelihood. Syst Biol 2003, 52:692-704.

38. Posada D: jModelTest: phylogenetic model averaging. Mol Biol Evol 2008 25:1253-1256.

39. Hasegawa M, Kishino H, Yano T: Dating of the human-ape splitting by a molecular clock of mitochondrial DNA. J Mol Evol 1985, 22:160-174.

40. Schwarz G: Estimating the dimension of a model. Ann Stat 1978, 6:461-464

41. Swofford DL, PAUP*: Phylogenetic analysis using parsimony ( ${ }^{*}$ and other methods). Version 4.0b10. Sunderland, MA: Sinauer Associates; 2001

42. Excoffier L, Laval G, Schneider S: Arlequin ver. 3.0: an integrated software package for population genetics data analysis. Evol Bioinform Online 2005, $1: 47-50$

43. Kimura M: A simple method for estimating evolutionary rate of base substitution through comparative studies of nucleotide sequences. $J \mathrm{Mol}$ Evol 1980, 16:111-120.

44. Mantel N: Detection of disease clustering and a generalized regression approach. Cancer Res 1967, 27:209.

45. Goudet J, FSTAT: A Program to Estimate and Test Gene Diversities and Fixation Indices, Version 2.9.3.2. 2002. Available at: http://www.unil.ch/Jahia/ site/dee/op/edit/pid/36921.

46. Akaike $\mathrm{H}$ : Information theory as an extension of the maximum likelihood principle. In Second International Symposium on Information Theory. Edited by Petrov BN, Csaki F. Budapest: Akademiai Kiado; 1973:267-281.

47. Burnham KP, Anderson DR: Model Selection and Inference: A Pratical Information-Theoretic Approach. New York: Springer; 1998. 
48. Dupanloup I, Schneider S, Excoffier L: A simulated annealing approach to define the genetic structure of populations. Mol Ecol 2002,

11:2571-2581

49. Drummond AJ, Rambaut A: BEAST v1.4. 2006. Available at: http://beast.bio. ed.ac.uk.

50. Drummond AJ, Ho SYW, Rawlence N, Rambaut A: A rough quide to BEAST 1.4. 2007. Available at: http://beast.bio.ed.ac.uk.

51. Zamudio KR, Greene HW: Phylogeography of the bushmaster (Lachesis muta: Viperidae): implications for Neotropical biogeography, systematics, and conservation. Biol J Linn Soc 1997, 62:421-442.

52. Macey JR, Schulte JA, Larson A, Tuniyev BS, Orlov N, Papenfuss TJ: Molecular phylogenetics, tRNA evolution, and historical biogeography in anguid lizards and related taxonomic families. Mol Phylogenet Evol 1999, 12:250-272

53. Daniels SR, Mouton PFN, Du Toit DA: Molecular data suggest that melanistic ectotherms at the south-western tip of Africa are the products of Miocene climatic events: evidence from cordylid lizards. J Zool Lond 2004, 263:373-383.

54. Torres-Carvajal O, de Queiroz K: Phylogeny of oplocercine lizards (Squamata: Iguania) with estimates of relative divergence times. Mol Phylogenet Evol 2009, 50:31-43.

55. ESRI: ArcG/S Desktop: Release 9. Redlands, CA: Environmental Systems Research Institute; 2011.

doi:10.1186/1471-2148-12-67

Cite this article as: Dubey et al:: Phylogeography and dispersal in the velvet gecko (Oedura lesueurii), and potential implications for conservation of an endangered snake (Hoplocephalus bungaroides). BMC Evolutionary Biology 2012 12:67.

\section{Submit your next manuscript to BioMed Central and take full advantage of:}

- Convenient online submission

- Thorough peer review

- No space constraints or color figure charges

- Immediate publication on acceptance

- Inclusion in PubMed, CAS, Scopus and Google Scholar

- Research which is freely available for redistribution 